\title{
Analysis of Sandbody Development Model in Lishui Depression
}

\author{
Guowei Hou ${ }^{1}$, Jinshui $\mathrm{Liu}^{1}$, Kun Cai ${ }^{1} \&$ Yonggang Wang ${ }^{1}$ \\ ${ }^{1}$ CNOOC, Co., Ltd. Shanghai branch, China \\ Correspondence: Jinshui Liu, CNOOC, Co., Ltd. Shanghai branch 200355, China. E-mail: dr.superhou@163.com
}

Received: March 22, 2018

Accepted: April 6, $2018 \quad$ Online Published: July 9, 2018

doi:10.5539/esr.v7n2p74

URL: https://doi.org/10.5539/esr.v7n2p74

\begin{abstract}
To a certain extent, the development of sand body in lishui depression determines the success of oil and gas exploration, so the development models of sand body become the focus of current research. Based on seismic interpretation and exploration practice, five types of sand body development model were developed in lishui depression, including gentle slope-valley typed sand control model, steep slope-valley typed sand control model, trough fault controlling axial typed sand control model, gentle slope -contemporaneous fault typed sand control model and bulge steep slope-cross section typed sand control model.

Different sand body development model determines the development characteristics of sand body and indicates the direction of exploration.

Keywords: lishui depression, sand control model, gentle slope belt, steep slope belt, trough fault

\section{Introduction}

Since lishui 36-1 gas field was discovered in 1997, lishui sag has not made great progress. The key reason is that the shallow structural target is not developed and lingfeng group in the middle-deep is buried deep, which cause sandstone reservoir is difficult to predict. The prediction method of the deep reservoir is mainly using geophysical method to predict sand body which is lack of effective geological model guidance. In recent years (2013), such as $\mathrm{Xu}$ Changgui viewed sediment from erosion to handling, stacking of the sedimentary dynamic process as a whole "source-sink system" and introduced into the reservoir, which made a good application effect in the bohai study area. Lin Changsong (2015) thought that denudation physiognomy and sediment were linked by sediment transport path, from the formation of denudation area source, carrying to the sedimentary area or finally deposited in the catchment basin, the process of which was called "source -sink system". This method is used to analyze the evolution of sedimentary system and predict the effective technology of sand body spreading, which provides reference for finding high-quality sandstone reservoir in lishui depression. There are multiple directions of the source in lishui depression, and two different types of petrology in east, west sub- depression, including Feldspar sandstone and lithic sandstone. There are significant differences in the physical characteristics of sandstone reservoirs with different source and petrology types. Based on seismic and drilling data, liu junhai (2004) discussed the polysand model of lishui depression to guide the oil and gas exploration in lishui depression.
\end{abstract}

\section{The General Situation of Regional Geology}

The Lishui Depression is located in the southwestern part of the Taipei Basin in the East China Sea continental shelf. The western and southern parts of the Lishui Depression connect with Fujian and Zhejiang uplifts. The eastern part of the Lishui Depression is the Yandang Protuberance and the Jiaojiang Depression is in the north. The interior is divided by the Lingfeng Qianshan for the Lishui West concave and the Lishui East concave. It is generally distributed in the NE direction, and is a Cenozoic graben depression characterized by a typical "EastWest-West" feature formed on the basement of the Mesozoic residual basin(Figure 1). The Lishui Depression experienced three tectonic evolution stages during the fault depression, depression and regional subsidence, developed Upper Cretaceous to Quaternary strata, lacked the Eocene and Oligocene strata, Layers of the GuiFeng Formation, Lingfeng Formation and Mingyuefeng Formation are developed from bottom to top. 

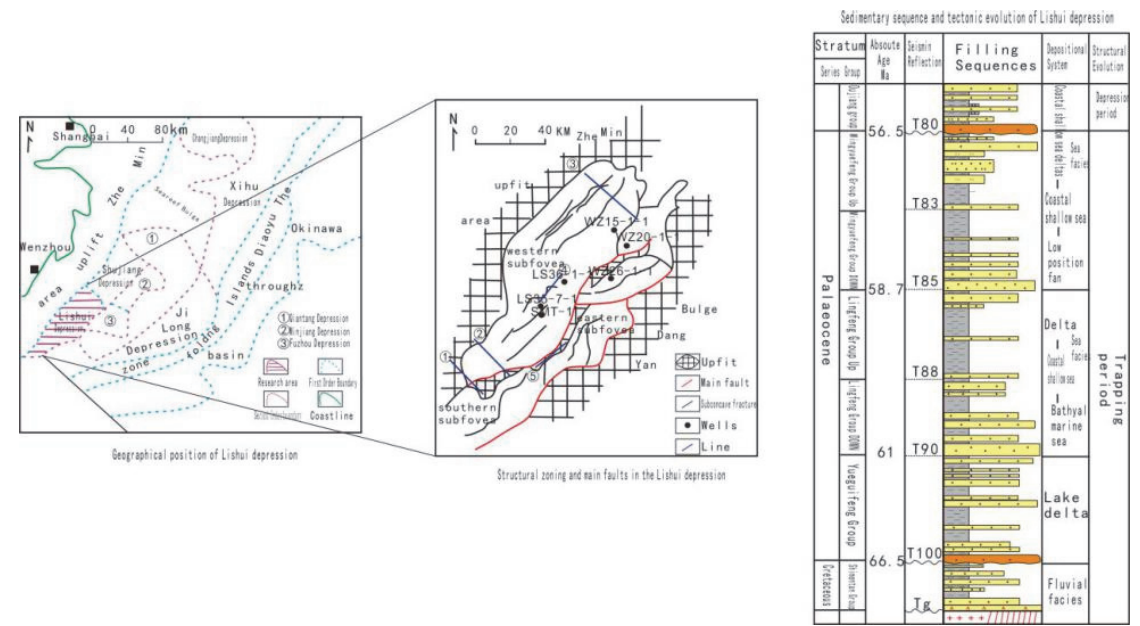

Figure 1. Regional Geological Background and Filling Sequence in Lishui Depression (According to Tian Bing et al (2012) modified)

\section{Sand Control Model with Gentle Slope}

\subsection{Gentle Slope-Valley Typed Sand Control Model}

It is mainly developed in the western slope of the West Secondary Depression. It is mainly developed in the western gentle slope belt of the western sub-depression. It is a delta-low fan depositional system controlled by factors such as fracture slope, sea-level decline and sediment supply. There are multiple undercutting Valley to the west of the fault slope, which indicates that the water erosion is obvious during this period, and the cutting Valley becomes the channel for the delta front sand body to converge to the basin. In the low stand system tract, the sand bodies under sea level descend and strong hydrodynamic conditions formed a series of flower bloom bodies along the undercut valleys, accumulating in the space below the slope fold. During the transgressive system tract, the sea level continued to rise, and the range of the basin continued to expand. The sedimentary bodies continuously retreated to form thick mudstone caprocks, thus forming a good reservoir-cap assemblage. A typical example of this model is a lithologic reservoir oil and gas developed from the lower fan-group of the lower Mingyuefeng Formation in the Lishui 36-1 gas field (Figure 2).

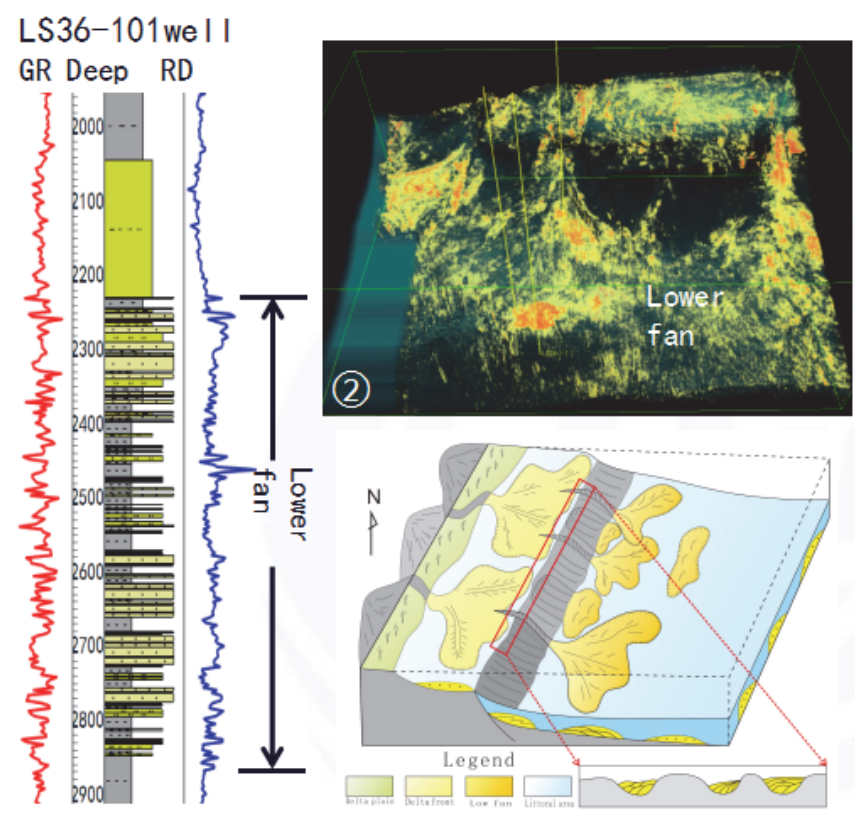

Figure 2. Gentle slope-valley typed sand control model 


\subsection{Gentle Slope-Contemporaneous Fault Typed Sand Control Model}

In the gentle slope belt in the central and southern part of the Xi Sag in the Lishui Depression, the progressive fault with the NND direction is dominant, which constitutes the stair-like feature on the terrain. The sand bodies provided by the source region of the Fujian-Zhejiang uplift belt in west China are transported into the sag under the gentle slope background. Due to the influence of syn-fault faults, the tidal flats and sand bodies are enriched by the tidal or wave transformation, spread the scope of the expansion. The LS35-7-1d Jinglingfeng Formation deposition in the work area is the sand control mode of syngenetic fault.A large set of sandstone with a thickness of over 300 meters has been formed in the fault depression plate(Figure 3).

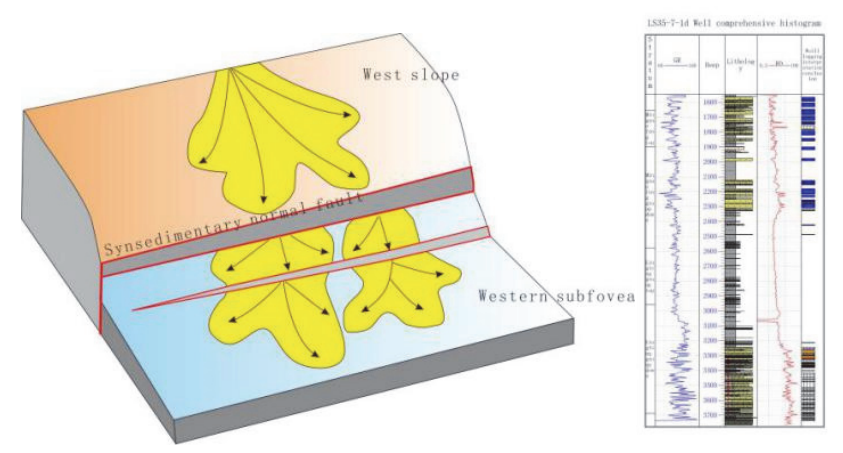

Figure 3. Gentle slope with the same fault sand control mode

\section{Steep Slope with Sand Control Mode}

\subsection{Steep Slope-Valley Typed Sand Control Model}

A large basin-edge fracture surface tends to be undulating. In particular, large dip faults tend to act as large slopes in their own right, and large erosion valleys often develop on these large fracture surfaces. These erosion valleys, the marginal faults and the source areas of the bump merge together to form a steep-slope gully sand control system. The sedimentary system formed under this source-sink system tends to be skirt-shaped at the foot of the slope, and the distribution range depends on the size of the valley (Xu Changgui et al., 2013).There are a number of erosion valleys on the west side of the buried hill in the south of the LS36-2-1 well in the Lishui Depression, with a width of $1.6 \mathrm{~km} \sim 3.2 \mathrm{~km}$, a length of $3.8 \sim 5.9 \mathrm{~m}$ and a depth of $75 \sim 173 \mathrm{~m}$. The basement lithology is metamorphic. For example, the SMT-1 Jingxi Formation thick sandstone in the Xi sub-depression is derived from sedimentary sand bodies carried by one of the valleys and has a coarse grain size and a large thickness, indicating near-source characteristics (Figure 4 ).Seismic data show that the coupling characteristic of "ditch-fan" is more obvious. It is speculated that a large number of fan-delta are developed in this area, forming skirt-like fan-groups at the foot of slope, forming steep-slope gully sand control mode, Of the material supply area, for the favorable reservoir in the central and western parts of the West to provide the material basis for the development.

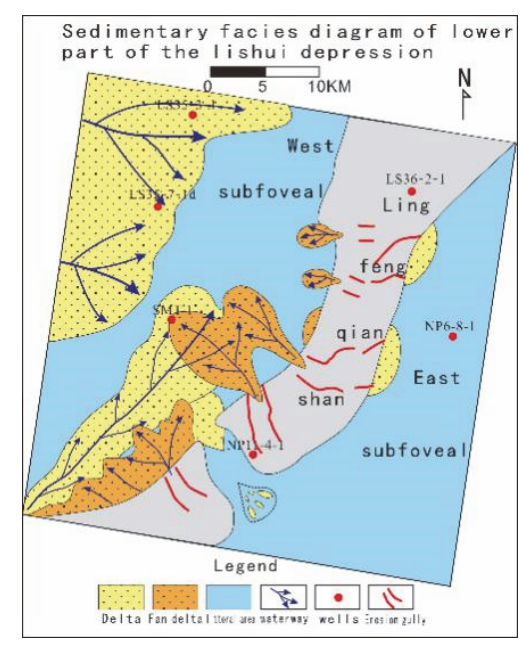

Figure 4. Steep slope-valley typed sand control model of Lishui Depression 


\subsection{Bulge Steep Slope-Cross Section Typed Sand Control Model}

Sand-controlling model of cross section in uplift steep slope zone is mainly developed in the east subconcave steep slope zone of Lishui sag, which is composed of straight boundary faults, the boundary faults are strongly active, on the one hand, it provides enough room for sediment deposition, on the other hand, the uplifted side becomes a denudation area, providing sufficient material supply for sediment deposition.WZ27-1-1 has been drilled into fan delta fan in the steep slope zone of the east subconcave depression in Lishui sag, in which $120 \mathrm{~m}$ thick sandy gravel is drilled, the coarse-grained sand body near the source is dominant, and the vertical scale is large along the section of steep slope zone, but its plane distribution scale is limited.

\section{Trough Fault Controlling Axial Typed Sand Control Model}

Lishui sag is a typical "east fault west super" graben sag with the characteristics of "north low and south high" in topography,the southwest of the west sub-depression is connected with the sea, which provides a passage for the sea water to enter the west sub-concave when the tide rises, it also provides energy condition and material supply for sand body accumulation in long axis direction.At the same time, the length of the long axis of the west subconcave is large, and the steep slope zone is close to the Lingfeng buried hill zone. The near source coarse fan delta sand body formed by the accumulation of buried hill material to the west sub-concave can be transported long distance to the middle part of the west sub-concave under the carrying of axial flow, which provides a better reservoir development condition for the structure developed in the middle of the west sub-concave. From the 3D seismic profile, the characteristics of forward reflection are obvious. The attribute data show that the sediments converge along the fault trough (the low position between reverse normal fault F1 and reverse normal fault F2) to the low potential area during the lower part of Lingfeng formation. The delta sedimentary sandbodies with axial distribution are distributed from Lingfeng buried hill to basin, and the distribution area of sand bodies is larger (Figure 5).

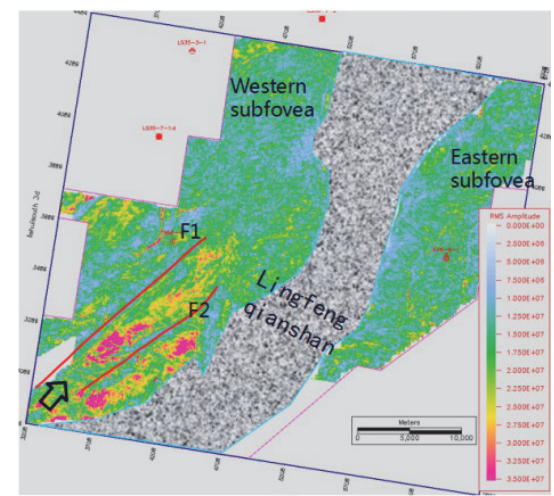

Figure 5 A

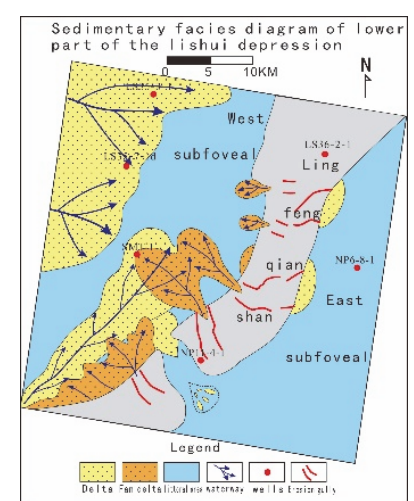

$\mathrm{n}$

\section{Conclusion}

The Lishui sag developed three types of five kinds of poly sand model.They are the controlling sand body model of gentle slop belt gully type,the controlling sand body model of steep slop zone gully type,the controlling sand body model of fault trough control axial direction,the controlling sand body model of gentle slop belt contemporaneous fault and the controlling sand body model of salient steep slop zone.The controlling sand body model of steep slop zone gully type is a favorable model development of sand body for Mingyuefeng Formation shallow layers. The controlling sand body model ofsteep slop zone gully type and the controlling sand body model of fault trough both are favorable model for the deep Lingfeng Formation and Yueguifeng Formation in the middlesouthern part of west subsag of Lishui sag. The controlling sand body model of salient steep slop zone is a favorable model development of sand body for the east subsag of Lishui sag.

\section{Acknowledgements}

This research work was funded by Major Projects of National Science and Technology "Sedimentary mechanism and geological prediction technology of deep dominant reservoirs" (Grant No. 2016ZX05027-002-007).

\section{References}

Hou, G. W., Liu, J. S., \& Zhou, R. H., et al. (2015). Lower fan fan deposition pattern in Lishui Sag, 27(5), 240- 
244.

Lin, Ch. S., Xia, Q. L., \& Shi, H. Sh., et al. (2015). Landform Evolution, Source - sink Processes and Basin Analysis[J]. Geoscience Frontiers, 22(1), 9-20.

Liu, J. H., Yang, X. H., Wu, \& Zh. X., et al. (2004). Analysis of Tracing of Zircon Uneassarite Traps in Lishui Sag, East China Sea BasinJ]. Marine Geology and Quaternary Geology, 24(1), 85-92.

Li, Y. J., Wei, J. H., \& Yao, Ch. L., et al. (2009). LA-ICP-MS zircon U-Pb chronology and its tectonic significance of the Shihuanchuan granite in southeastern Zhejiang Province. Geological Review, 55(5), 673-684.

Qiu, J. Sh., Liu, L., \& Li. Zh. (2011). U-Pb zircon zircon U-Pb geochronology and Sr-Nd-Hf isotopic geochemistry of the Wanghaigang quartzite in Huangyan, Zhejiang, and their constraints on the genesis of the rock. Acta Petrologica Sinica, 27(6), 1557-1572.

Qiu, J. Sh., Xiao, E., \& Hu, J., et al. (2008). Origin of high-grade I-type granites along the coast of northern Fujian: zircon U-Pb geochronology, geochemistry and Nd-Hf isotopic constraints. Acta Petrologica Sinica, 24(11), 2468-2484.

Tian, B., Pang, G. Y., \& Wang, Q., et al. (2012). Hydrocarbon Accumulation Conditions in the superimposed and Subsided Basin - A Case Study of Lishui - Jiaojiang Depression in the East China Sea. Lithologic Reservoirs | Lith Res, 24(5), 32-37.

Wang, D. Z., Zhao, G. T., \& Qiu, J. Sh. (1995). Constraints on Late Mesozoic A - type Granites in Eastern China[J]. Geological Journal of China Universities, 1(2), 13-21.

Xin, G. F., Tao, G. Y., \& Yang, Z. L., et al. (1999). Genesis and Prospect of Mesozoic Volcanic Rocks in Southeast Coast of China. Bulletin of Mineralogy, Petrologu And Geochemistry, 18(3), 189-193.

Xu, Ch. G. (2013). Terrestrial faulted basin source-sink time-space coupling Principle of sand control: basic idea, conceptual system and sand control mode[J]. China Offshore Oil and Gas, 25(4), 1-11.

\section{Copyrights}

Copyright for this article is retained by the author(s), with first publication rights granted to the journal.

This is an open-access article distributed under the terms and conditions of the Creative Commons Attribution license (http://creativecommons.org/licenses/by/4.0/). 